\title{
Prevention of Children Sexual Abuse by Active Learning to Elementary School Students in West Jakarta Indonesia
}

\author{
Safitri M*, Aziz Luthfi, Euis Heryati \\ Faculty of Psychology, Universitas Esa Unggul, Indonesia
}

Copyright $(2019$ by authors, all rights reserved. Authors agree that this article remains permanently open access under the terms of the Creative Commons Attribution License 4.0 International License

\begin{abstract}
The number of sexual abuse in children as the victims has increased year to year. Technology development is believed as one of the reasons the increasement of sexual abuse. The purpose of this research is to give the knowledge and get a picture that happened to children about sexual abuse by making visual model and share it by active learning method. This study is using quasi experiment method, through training with Active learning method. The respondents are 232 students from 3 elementary school in West Jakarta Indonesia. The measurement data of sexual abuse knowledge with pre and post questionnaire, and peer group discussion. The results showed that many students still in the not knowing the kinds of sexual abuse and or who possibly could be the offender, but few of them already recognized the kind of sexual behavior, either self-experience or from what they saw around them. The active learning method was effective to increase knowledge about the offender and the type of sexual abuse to Elementary School Students in West Jakarta Indonesia, with test results differ to p0, 00 .
\end{abstract}

Keywords Sexual Abuse, Children, Active Learning

\section{Introduction}

The phenomenon of sexual abuse to children becomes more often and it happened nearly in every country in the world. The number of sexual abuse to children keeps increasing time to time. The incensement is not only about the numbers or quantity, on 2013 out from 2.637 case of violence on children, $48 \%$ or about 1.266 cases were sexual abuse to children (Bakohumas, kominfo 2014).

The sexual abuse to children is one of torturing form to a child where adult or teenager, someone older than the child using him/her for seducing and fulfilling their sexual needs. The type of sexual abuse on children including asking and forcing a child to do sexual activity (regardless the outcome), exposing the child about something inappropriate from their genital to the child, exhibiting pornography to children, doing sexual activity with the children, make physical contact to children's genital, seeing the child's genital without physical contact or using the child to create children pornography.

From the news of sexual abuse, one of the causes is the offender affected from watching pornography scene. Safitri research in the last 2016 resulted most elementary students in West Jakarta have seen picture or porn scene $(86,3 \%)$. The tendency level of pornography addiction tend to be intermediate. On Several cases of sexual abuse, it is discovered that the type of abasement was verbally and touching particular part of the body. It literally means that besides being the victims, the children can also be the offender or the subject of sexual abuse.

The rise of violence cases to children especially sexual abuse become some phenomena for modern society nowadays. Based on KPAI (Indonesian child protection committee) data, in 2018 there are 965 cases of violence, 52 percent are still dominated by sexual crimes. The child perpetrators increased to 26 percent. Where generally the average victim is 13 years old and the youngest is 2 years old. So, the offender and the object's age getting younger and younger each day. Children are susceptible to be the victims of sexual abuse because their dependency is high, meanwhile their ability to protect their selves from any harm is low. Traumatic to children with sexual abuse experience will be carried on in their lives. And it should have been our concern more because not only they are obligatory protected wherever and whenever, but also in the hands of children the future of a nation will be developed. This journal described a picture of sexual abuse that happened to children, how to raise the children acknowledged by making visual model to detect earlier and to prevent the sexual abuse to children. 


\section{Literature Review}

Abuse is the part of aggression, and it is on purpose act by someone to another (Berkowitz, in Sarwono 2017). The children become more fragile because of his/her social position in the society (Freyd, 2005, in Sarwono 2017), sexual abuse to children generally done by siblings, neighbors and or the baby sitter.

The definition of sexual abuse (Siti Hikmah, 2017) is a sexual behavior which is extremely neither unwanted nor expected by the object or the victim that will lead to disruption of the victim.

The type of sexual abuses described above can be categorized as:

a. Verbal Sexual Abuse.

This kind of abuse can be manifested in saying/words to other people related to something sexually, Such as joke, whistling, asking question to another people about sexual wish, Criticizing or giving out comment about physical related to sexual part.

b. Non- verbal sexual abuse.

The non-verbal sexual abuse is the opposite of verbal harrasment. if previously in verbal sexual abuse used more invitation in the form of words, saying or writing, in non-verbal category, the subject tend to used direct behavior more often without physical contact, for example : 1) Exhibitioning his genital in front of others individually or to some people at once. 2) Looking at another person sexual part of the body harassly 3) Scraping their genial to other people

c. Physical sexual abuse.

In this category sexual abuse between the subject and the victim has been contacted physically, it can be divided into light and heavy such as 1) groping someone's part of body which is extremely unwanted.2) Rape or coercion to have sexual activity.

Children development affected by continuity phase from family, friends, and teachers. A child's world is expanding because they're growing and developing relationship with many new people around them which will affect their socioemotional development. One of the theory talking about this is the ecology theory belonged to Bronfenbrenner.

Bronfenbrenner's ecology theory (in Santrock 2014) consist of 5 environments, started from interpersonal relations up to the impact of culture broadness. The five systems are microsystem, mesosystem, exosystem, macrosystem, nd chronosystem.

Today, microsystem influence children a lot earlier than ever. We can see that from how deep the technology affected our children, where the symptoms can be seen in learning process, they need some active learning methods.

According to Chatib (2011) active learning intended to optimize all the potentials of the students, so all of them can achieve the best result and evaluation in their academic with their own special characters. Other than that, active learning intended to make the students keep paying attention to the class instead of thinking or doing something else. Several study prove us that the student's attention is lacking due to the duration of their school time (Pollio's study in 1984, on Chatib 2011) showed the students in a classroom only paying attention while they study for about $40 \%$ from $100 \%$ clas time, Meanwhile the McKeachie (1986 on Chatib 2011) mentioned that the first 10 minutes, students focused achieved $70 \%$ and lacking into $20 \%$ at the last 20 minutes. Safitri study result (2013) explained that active learning method in learning statistical resulting effective impact where learning started from apperception in the form of motivation story.

\section{Research Method}

This research method uses quasi experimental, through training with Active learning method (brain gym, ice breaker, role play, psycho drama). This training is using visual model "AKU BERANI" (Children is able to protect and defend their self) to give the knowledge of sexual prevention, and will be closed with peer group discussion to get a deep understanding about the lesson material. The "BERANI" is the acronyms of B: my body is precious, E: no one is allowed touching me, R: feel if there's something uncomfortable, A: ignore unappropriated invitation, $\mathrm{N}$ : No is no, and I: remain to keep communication with parents or trusted relatives.

The subjects of this study are 232 students, at the $5^{\text {th }}$ and $6^{\text {th }}$ grade from 3 public school (A, B and C) located in West Jakarta Indonesia. The measurement data of sexual abuse knowledge with pre and post questionnaire, before and after the active learning training, and peer group discussion.

\section{Result and Discussion}

\subsection{Respondents Description}

The subjects are 89 students from School A, 116 students from School B and 27 students from School C. The most subjects are on the $6^{\text {th }}$ grades, 147 students, compare to $5^{\text {th }}$ grade which were consist of 85 students. School A consist 89 students on the $6^{\text {th }}$ grade, while school $\mathrm{B}$ consist of $5^{\text {th }}$ and $6^{\text {th }}$ grades, each 58 students per grade, the rest is school $\mathrm{C}$ consist of 27 students of $5^{\text {th }}$ grade. School $\mathrm{C}$ is chosen in purpose to see whether there will be any difference between a little and many participants.

The most participants are girls, consist of 122 students, meanwhile boy participants consist of 110 students. Both school A and B have more girl participants each 47 and 62 students, while the boys are 42 and 54 students each. School $\mathrm{C}$ has much more boys 14 students than the girls 
which are 13 students.

\subsection{Description about Sexual Abuse Experience}

The Description of witness sexual abuse can be seen on table 1 .

Based on table 1, we can see that most participants have witness the sexual harassment 175 students $(75,4 \%)$ and the rest has never witness the sexual harassment $(24,6 \%)$. Students of school A, B, and C mostly have witness as much 69 persons (77,5\%), $85(73 \%)$ and $21(77,7 \%)$ students. Those who never witness sexual abuse from school A, B and C each are 20 (22,5\%), 31 (27\%) and 6 $(22,3 \%)$ of students.

The Description place of witness sexual harassment can be seen on table 2 as follow.
Based on table 2, most participants witness sexual harassment on television as many $202(87,1 \%)$ students, followed with handphone $15(6,5 \%)$ students, youtube 13 $(5,6 \%)$ students and games $2(0,8 \%)$ students. On elementary school A, B and $\mathrm{C}$ the venue where the participants witness the sexual abuse the most is from television each $79(88,8 \%)$ students, $104(89,7 \%)$ students and $19(70,3 \%)$ students. From table 1 and 2 showed that not only 175 students, but almost $202(87,1 \%)$ students have witness the sexual harassment.

According to Ade E. Mardiana (Sarwono, 2017) the show on television big possibly is imitated by the viewer. Television as media is a visual media and naturally has bigger chance for the viewer to watch the whole show and absorb the message

Table 1. Witness Sexual Abuse

\begin{tabular}{|l|c|c|c|c|}
\hline \multirow{2}{*}{ Witness sexual abuse } & \multicolumn{3}{|c|}{ School origin } & \multirow{2}{*}{ Total } \\
\cline { 2 - 5 } & $\mathrm{A}$ & $\mathrm{B}$ & $\mathrm{C}$ & $175(75,4 \%)$ \\
\hline Yes & $69(77,5 \%)$ & $85(73 \%)$ & $21(77,7 \%)$ & $57(24,6 \%)$ \\
\hline No & $20(22,5 \%)$ & $31(27 \%)$ & $6(22,3 \%)$ & $232(100 \%)$ \\
\hline Total & $89(100 \%$ & $116(100 \%)$ & $27(100 \%)$ & \\
\hline
\end{tabular}

Table 2. The Place of Witness Sexual Abuse

\begin{tabular}{|l|c|c|c|c|}
\hline \multirow{2}{*}{ Place of witness sexual abuse } & \multicolumn{2}{|c|}{ School origin } & \multirow{2}{*}{ Total } \\
\cline { 2 - 4 } & $\mathrm{A}$ & $\mathrm{B}$ & $\mathrm{C}$ & \\
\hline Television & $79(88,8 \%)$ & $104(89,7 \%)$ & $19(70,3 \%)$ & $202(87,1 \%)$ \\
\hline Handphone & $5(5,6 \%)$ & $4(3,4 \%)$ & $6(22,3 \%)$ & $15(6,5 \%)$ \\
\hline Youtube & $4(4,5 \%)$ & $7(6,0 \%)$ & $2(7,4 \%)$ & $13(5,6 \%)$ \\
\hline Games & $1(1,1 \%)$ & $1(0,9 \%)$ & $0(0 \%)$ & $2(0,8 \%)$ \\
\hline Total & $89(100 \%)$ & $116(100 \%)$ & $27(100 \%)$ & $232(100 \%)$ \\
\hline
\end{tabular}

Table 3. The Students Feeling Before Training

\begin{tabular}{|l|c|c|c|c|}
\hline \multirow{2}{*}{ Students Feeling before training } & \multicolumn{2}{|c|}{ School Origin } & \multirow{2}{*}{ Total } \\
\cline { 2 - 5 } & A & B & C & \\
\hline afraid & $0(0 \%)$ & $4(3,4 \%)$ & $0(0 \%)$ & $4(1,7 \%)$ \\
\hline ordinary & $16(18,0 \%)$ & $11(9,5 \%)$ & $2(7,4 \%)$ & $29(12,5 \%)$ \\
\hline happy & $51(57,3 \%)$ & $63(54,3 \%)$ & $9(33,3 \%)$ & $123(53,0 \%)$ \\
\hline Very happy & $22(24,7 \%)$ & $38(32,8 \%)$ & $16(59,3 \%)$ & $76(32,8 \%)$ \\
\hline Total & $89(100 \%)$ & $116(100 \%)$ & $27(100 \%)$ & $232(100 \%)$ \\
\hline
\end{tabular}

Table 4. The Students Feeling After Training

\begin{tabular}{|l|c|c|c|c|}
\hline \multirow{2}{*}{ Students feeling after training } & \multicolumn{3}{|c|}{ School origin } & \multirow{2}{*}{ Total } \\
\cline { 2 - 5 } & ES A & ES B & ES C & \\
\hline Afraid & $1(1,1 \%)$ & $0(0 \%)$ & $0(0 \%)$ & $1(0,4 \%)$ \\
\hline ordinary & $12(13,5 \%)$ & $2(1,7 \%)$ & $0(0 \%)$ & $14(6,0 \%)$ \\
\hline happy & $41(46,1 \%)$ & $25(21,6 \%)$ & $12(44,4 \%)$ & $78(33,6 \%)$ \\
\hline Very happy & $35(39,3 \%)$ & $89(76,7 \%)$ & $15(55,6 \%)$ & $139(60,0 \%)$ \\
\hline Total & $89(100 \%)$ & $116(100 \%)$ & $27(100 \%)$ & $232(100 \%)$ \\
\hline
\end{tabular}




\subsection{Program's Effectivity}

Effectivity program is done by difference test of the students feeling, the type of abuse, and the recognized or unrecognized offender before and after training.

The students feel before and after training in table 3 and 4.

Based on table 3, students feeling before going through the raining session, mostly are happy $123(53,0 \%)$ students, very happy $76(32,8 \%)$ students, ordinary $29(12,5 \%)$ students, and afraid $4(1,7 \%)$ students. On school A, most students felt happy 51 students, followed by very happy 22 students, and felt ordinary 16 students. On school B most students felt happy 63 students, followed by very happy 38 students, ordinary 11 students and feeling afraid 4 students. On school C, most students felt very happy 16 students, happy 9 students, and 2 students felt ordinary. The students from the same class (school C) seemed more confined to do this training.

Based on table 4, participants feeling after went through the program were very happy as much $139(60,0 \%)$ students, $78(33,6 \%)$ students felt happy, feeling ordinary $14(6,0 \%)$ students, and feeling afraid $1(0,4 \%)$ students. On school A, most students felt happy $41(46,1 \%)$ students, followed with very happy $35(39,3 \%)$ students, felt ordinary $12(13,5 \%)$ students, and feeling afraid $1(1,1 \%)$ student. On school B most participants 89 felt very happy $89(76,7 \%)$ students, followed by happy $25(21,6 \%)$ students, and ordinary 2(1,7\%) students. On school C most students felt very happy $15(55,6 \%)$ students, felt happy 12 ( $44,4 \%$ ) students. Statistical test of the feelings showing value $p=0,00$, it means there's a significant difference between students feelings before and after training.

This training is successful in providing knowledge with fun, can be used as an activity to prevent sexual abuse in children. Study Ummu Markwei (2019) in Ghana finding the need for effective preventive programs and community interventions to protect children and support victims of child sexual abuse. So this training can be proposed to be one of the programs to prevent sexual abuse in children

The type of sexual abuse which is known before and after the training session can be seen at the table 5 .

Based on table 5, we can see that before the education session, the type of sexual harassment for the student of school A,B and C usually recognized were rape, as much $53(59,6 \%), 83(71,6 \%)$ and $18 \quad(66,7 \%)$ students . Meanwhile after education, on school A, most participate aware the type of sexual abuse of touching, groping and squeeze the forbidden part of the body, and rape were each $73(82,0 \%)$ students, and students on School B aware the most about touching or forbidden part of the body 91 students $(78,4 \%)$. Students on school C mostly aware of the sexual abuse type of touching groping and squeeze the forbidden part of the body and rape, were each 20 (74 \%) students.

Table 5. The Type Of Sexual Abuse

\begin{tabular}{|c|c|c|c|c|c|c|}
\hline \multirow{2}{*}{ Type of sexual abuse } & \multicolumn{3}{|c|}{ Before training } & \multicolumn{3}{|c|}{ After Training } \\
\hline & $\mathbf{A}$ & B & C & $\mathbf{A}$ & B & C \\
\hline Naughty whistle & $\begin{array}{c}21 \\
23,5 \% \\
\end{array}$ & $\begin{array}{c}16 \\
13,8 \% \\
\end{array}$ & $\begin{array}{c}16 \\
59,2 \% \\
\end{array}$ & $\begin{array}{c}36 \\
40,4 \% \\
\end{array}$ & $\begin{array}{c}48 \\
41,3 \% \\
\end{array}$ & $\begin{array}{c}18 \\
66,7 \% \\
\end{array}$ \\
\hline Porn joke & $\begin{array}{c}34 \\
38,2 \%\end{array}$ & $\begin{array}{c}34 \\
29,3 \%\end{array}$ & $\begin{array}{c}8 \\
29,6 \%\end{array}$ & $\begin{array}{c}41 \\
46,1 \%\end{array}$ & $\begin{array}{c}51 \\
43,9 \%\end{array}$ & $\begin{array}{c}12 \\
44,4 \%\end{array}$ \\
\hline Exhibition & $\begin{array}{c}35 \\
39,3 \% \\
\end{array}$ & $\begin{array}{c}38 \\
32,7 \% \\
\end{array}$ & $\begin{array}{c}4 \\
14,8 \% \\
\end{array}$ & $\begin{array}{c}47 \\
52,8 \% \\
\end{array}$ & $\begin{array}{c}56 \\
48,2 \% \\
\end{array}$ & $\begin{array}{c}11 \\
40,7 \% \\
\end{array}$ \\
\hline $\begin{array}{l}\text { Touching, gro ping squeeze } \\
\text { Forbidden part }\end{array}$ & $\begin{array}{c}47 \\
52,8 \% \\
\end{array}$ & $\begin{array}{c}71 \\
61,2 \% \\
\end{array}$ & $\begin{array}{c}10 \\
37,0 \% \\
\end{array}$ & $\begin{array}{c}73 \\
82,0 \% \\
\end{array}$ & $\begin{array}{c}91 \\
78,4 \% \\
\end{array}$ & $\begin{array}{c}20 \\
74,0 \% \\
\end{array}$ \\
\hline Voyeuris & $\begin{array}{c}17 \\
19,1 \%\end{array}$ & $\begin{array}{c}14 \\
12,0 \%\end{array}$ & $\begin{array}{c}9 \\
33,3 \% \\
\end{array}$ & $\begin{array}{c}39 \\
43,8 \% \\
\end{array}$ & $\begin{array}{c}47 \\
40,5 \%\end{array}$ & $\begin{array}{c}16 \\
59,2 \%\end{array}$ \\
\hline Rape & $\begin{array}{c}53 \\
59,6 \%\end{array}$ & $\begin{array}{c}83 \\
71,6 \%\end{array}$ & $\begin{array}{c}18 \\
66,7 \%\end{array}$ & $\begin{array}{c}73 \\
82,0 \% \\
\end{array}$ & $\begin{array}{c}90 \\
77,6 \% \\
\end{array}$ & $\begin{array}{c}20 \\
74,0 \% \\
\end{array}$ \\
\hline
\end{tabular}

Table 6. Sexual Offender Which is Recognized By The Students Before And After Training

\begin{tabular}{|c|c|c|c|c|c|c|}
\hline \multirow{2}{*}{ Sexual offender } & \multicolumn{3}{|c|}{ Before Training } & \multicolumn{3}{|c|}{ After Training } \\
\hline & $\mathbf{A}$ & B & $\mathbf{C}$ & $\mathbf{A}$ & B & $\mathbf{C}$ \\
\hline father & $\begin{array}{c}19 \\
21,3 \% \\
\end{array}$ & $\begin{array}{c}10 \\
8,6 \%\end{array}$ & $\begin{array}{c}6 \\
22,2 \% \\
\end{array}$ & $\begin{array}{c}27 \\
30,3 \% \\
\end{array}$ & $\begin{array}{c}26 \\
22,4 \%\end{array}$ & $\begin{array}{c}10 \\
37,0 \%\end{array}$ \\
\hline uncle & $\begin{array}{c}5 \\
5,6 \% \\
\end{array}$ & $\begin{array}{c}1 \\
0,8 \% \\
\end{array}$ & $\begin{array}{c}1 \\
3,7 \% \\
\end{array}$ & $\begin{array}{c}32 \\
35,9 \\
\end{array}$ & $\begin{array}{c}34 \\
29,3 \% \\
\end{array}$ & $\begin{array}{c}13 \\
48,1 \% \\
\end{array}$ \\
\hline Grand father & $\begin{array}{c}10 \\
11,2 \%\end{array}$ & $\begin{array}{c}4 \\
3,4 \% \\
\end{array}$ & $\begin{array}{c}4 \\
14,8 \% \\
\end{array}$ & $\begin{array}{c}12 \\
13,4 \%\end{array}$ & $\begin{array}{c}15 \\
12,9 \%\end{array}$ & $\begin{array}{c}7 \\
25,9 \%\end{array}$ \\
\hline Teacher & $\begin{array}{c}7 \\
7,8 \% \\
\end{array}$ & $\begin{array}{c}6 \\
5,1 \% \\
\end{array}$ & $\begin{array}{c}3 \\
11,1 \% \\
\end{array}$ & $\begin{array}{c}23 \\
25,8 \% \\
\end{array}$ & $\begin{array}{c}17 \\
14,6 \% \\
\end{array}$ & $\begin{array}{c}13 \\
48,1 \% \\
\end{array}$ \\
\hline Familiar person & $\begin{array}{c}30 \\
33,7 \% \\
\end{array}$ & $\begin{array}{c}28 \\
24,1 \% \\
\end{array}$ & $\begin{array}{c}2 \\
7,4 \% \\
\end{array}$ & $\begin{array}{c}77 \\
86,5 \% \\
\end{array}$ & $\begin{array}{c}92 \\
79,3 \% \\
\end{array}$ & $\begin{array}{c}20 \\
74,1 \% \\
\end{array}$ \\
\hline Stranger & $\begin{array}{c}70 \\
78,6 \%\end{array}$ & $\begin{array}{c}104 \\
89,6 \%\end{array}$ & $\begin{array}{c}23 \\
85,1 \%\end{array}$ & $\begin{array}{c}87 \\
97,7 \%\end{array}$ & $\begin{array}{c}111 \\
95,7 \%\end{array}$ & $\begin{array}{c}26 \\
96,3 \%\end{array}$ \\
\hline
\end{tabular}


The majority of children are more familiar with rape in a type of sexual violence, whereas many cases of sexual violence occur more than that. Besides from KPAI data in Indonesia, the study of sex offender in New Jersey from Kristen M. Zgoba (2019) showed 79 percent of the offenses were child molestations and 20 percent were rapes

Description of the sexual offender students recognized before and after education can be seen on table 6 .

Based on table 6 , we can see that before education, students of school A, B, and C mostly aware of stranger offender, which each are 70 students $(78,6 \%), 104(89,6 \%)$, and 23 students $(85,1 \%)$. Meanwhile after the education, the sexual offender mostly are absolute strangers which each were 87 participants $(97,7 \%), 111(95,7)$ dan 26 participants $(96,3 \%)$ students.

The majority of children are more familiar that stranger as the sexual offender. Meanwhile many cases showed that the offenders stay near around the victim. Diesmy Humaira B (2015) study result concluded that from 16 cases mostly were doing by the familiar person around the child by seducing or lure with something. A 2006 report (Chris Dornin ) for the Ohio Sentencing Commission said 93 percent of molestation victims were well known to their perpetrators, over half the offenders victimized close relatives. Study in New Jersey from Kristen M. Zgoba (2019) also showed in 48 percent of the cases, the sex offender was a member of the victim's family. In 42 percent of the cases, the perpetrator lived with the victim.

Statistical test of sexual type and the offender knowledge showing value $p=0,00$, it means there's a significant difference between students' knowledge about sexual type and the sexual offender, before and after training.

\subsection{Peer Group Discussion Result}

After the students gained the prevention sexual lesson, they will be guided to discuss each other, accompanied and facilitated by a college student (considered as peer). Each group consists of 8-10 students, divided between boys and girls. Facilitator also selected with the same gender, by doing so, students are expected to be more up open talking in that discussion.

Some findings gained from discussion are as follow:

- Several students saw their man teacher touching girl student's breast and her thigh

- Students acknowledged sexual term from what they heard through adult's talking around them such as mother, brother, sister, and so on

- One of the students has an FB account and saw a friend posting self-picture in nudity, and then that student stop being friend in Facebook and report that friend to FB.

- One student suddenly stop talking when the topic was about LGBT, and then making defense and turn his/her body the other way around to avoid the discussion
- One student just doing fun by playing girlfriend genital

- Many students already acknowledged masturbating

- Students putting down his pants, and kiss, and hugged

- A teacher used to swipe his beard to students

- Starter, swipe and scrape between boy

- Monger at school selling toys, and lure the students with an offer and ask the victim to do sexual activity

- A student was about to be raped, but refused

- Construction laborers around the school were doing naughty whistle to girl students

- Boy students do peeking girl students at the toilet

- Neighbor actively asked to do the sexual activity

- The monger around the school were touching on purpose

- Masjid keeper were touching

- Neighbor asking to the alley

- Asking to go to sleeping room

- Online transporter forcing of touching

- Watching porn video or masturbating in the class

- Video call while in the shower, asked to undressed

- There's a preference of the same gender relationship, girl kissing girl, boy kissing boy

- Girl students playing sexual arousing thing by squeeze and stuff

- Man teacher/ lecturer is poking chin or hip

- When students played, a man came over and exhibited his genital over the children

- Pushing one another on purpose to hit breasts

- Watching YouTube, and accidentally watch the porn commercial break

- Having boy friends at house, all of them loved to watch porn video

- Starter on the pole and felt tickled

- acknowledged there's an unvarying around and been used by so many people

- Get a starter from a friend, and reply

- A friend at house already engage in dating because feeling the need to make direct contact of the body sexually

- Boy students peeking up girl at the rest room, and break down the door

- Watching bigolife, someone is asking introducing with mini clothes on.

From this peer discussion showed that many of the elementary students were actually already a victim at the house neighborhood, so many students has become so close with being victims of sexual abuse. A December 2009 study by David Finkelhor of UNH and colleagues for the US Justice Department analyzed national sex crime data from 2004. The study said that one in eight juvenile sex offenders were under age 12, between 85 and 95 percent of young offenders would never face another sex charge. 


\section{Discussion}

Based on data gained, it's seen that most students as much $175(75,4 \%)$ already acknowledged the sexual abuse, although there were some who didn't $(24,6 \%)$, It possibly they actually knew already, but they did not realize that it was the kind of sexual abuse. Most of them, seen that on TV (87\%). According to Ade E. Mardiana (Sarwono, 2017) the show on television big possibly is imitated by the viewer. Television as media is a visual media and naturally has bigger chance for the viewer to watch the whole show and absorb the message. Study results of Hadad and Glasman (2004 on Sarwono 2017) about correlation between abusive behavior and television with the conclusion as follow "watching violence will increase agressivity" it came out with the results that the most impacting show on television is soap opera (SINETRON) 29,7\%. According to Kastlaman M (2007), seeing pornography also raise porn mentality. This can be used as input for parents to always accompany their children while watching television, because much violence were showed in SINETRON. It's quite possible that the children will copy the sexual abuse they saw from television at the first place.

Based on the type of sexual abuse a child acknowledged, the most activity they aware were rape, touching, groping, squeeze of the forbidden part of a body, and also naughty whistle. Study of sex offender in New Jersey from Kristen M. Zgoba (2019) showed 79 percent of the offenses were child molestations and 20 percent were rapes. It literally means that those activities are categorized as sexual abuse and started to find around the students environment. It is also possible that the copy behavior from what they saw on television already done.

Besides, parent and teachers must be aware of hand phone and you tube, the place where they saw sexual abuse. Ideally, the elementary students spend most of the time to interact with other people directly (micro system). Electronic devices are media to interact with other people directly (macro system) and also get information from other people indirectly. Giving electronic devices without any obvious explanation and direction from parents will endanger the users. Data indicates that hand phones are the basic needs of children. Even though, most of the children use hand phones for communication, but they could incidentally see a lot of info about pornography that could be caused sexual abuse.

Elementary children are still at the phase of concrete thought by cognitive development. Therefore, direct interaction with other people is still much better and required for self-development. Working parents and mother's educational level make direct interaction with parents diminish. While, children get a lot of information by internet in their gadget. Facilities they received facilitate them to get any information from friends or internet. Moreover, awareness and times to surf the internet are getting higher.

Their curiosity of information on sexual development is not directly received from close adults in their micro environment, therefore they find out the information on their own or together with the peers who are also curious. Information received by internet can cause children to behave badly such as sexual abuse, while parents as directors fail to fully realize the effects thereof.

It complies with Hurlock's theory (2007) that each age has certain stages of development. One of the aspects is socio-emotional and social development affected by successive waves from family, friends, and teachers. The small world of children widens because they grow bigger and develop their relationships with many new people that will influence their socio-emotional development. According to ecological theory of Bronfenbrenner (in Hurlock 2007), there are five environments ranging from interpersonal interaction to extensive culture-based effects. The five systems are microsystem, mesosystem, ecosystem, microsystem, and chronosystem. Therefore, children ideally need step-by-step guidance by completing well the tasks of their development in the micro system to enter the micro system.

The peeking another person while they're in the shower were only acknowledged by few students $(17,2 \%)$ at first, but after the training, it's increased up to nearly $45 \%$. This leads us to an understanding that lots of children did not realize that their boyfriend prank were kind of sexual abuse type. Therefore, it is required an extra effort from the parents and teachers to keep reminding the students and increase their awareness of sexual abuse around them and the type of behavior.

On the sexual offender, most student acknowledged that the offender were absolute strangers $(84,9 \%)$, meanwhile uncle 3\%. Diesmy Humaira B (2015) study result concluded that from 16 cases mostly were doing by the familiar person around the child by seducing or lure with something. Out from 12 cases sexual abuse were done at the house of the victim or the offender, another 2 cases were done at the place where the children used to go to, like school, relatives house, meanwhile the rest of case were usually done in unusual places for the victims, such as hotel, and the pile of banana trees. A 2006 report for the Ohio Sentencing Commission said 93 percent of molestation victims were well known to their perpetrators, over half the offenders were close relatives. Study in New Jersey from Kristen M. Zgoba (2019) also showed in 48 percent of the cases, the sex offender was a member of the victim's family. In 42 percent of the cases, the perpetrator lived with the victim, and in 77 percent of the cases, the crime occurred in the victim's or offender's home. From the discussion, there's finding that most of the elementary students were actually already a victim at the house neighborhood, so many students have become so close with being victims of sexual abuse. The children need to be reminded that the offenders usually are the closest person 
around them.

So that with the teacher as the offender, only $6,9 \%$ who already said that teacher is one of the offender, although some students may have seen or felt that the impact of their teacher doing so. At the early 2018, KPAI (Indonesian child protection committee) had received many reports related to sexual abuse done by the teacher, headmaster, another school officer, and the student itself. This sexual abuse behavior at school, were done in almost all over school area such as at the camp side, and in the bus tourism. For cases with teacher as the offender, they choose place like restroom, classroom, students organization's room, or even at the prayer room near the carpet storage. Teacher as offender also came with variety position, like homeroom teacher, subject teacher such as teaching Bahasa, sports, and even religion. KPAI pushed the school to open a complaint shelter and encourage the students who are brave enough to report harassment in physical, psychological, financial, or sexual, with protection system for the child as victim and as witness, those who report the violence will be guarantied for protection.

The knowledge about type and sexual abuse becomes better after the training of "AKU BERANI" (Children is able to protect and defend their self), which is using active learning method combined with visual audio. From brain gym followed by songs and body movements, video Comal show, my body is precious video, and good and bad touch song also spirit song Bangun Pemuda Pemudi. The addition of visual to a learning process can increase memory up to $171 \%$ compare to the beginning. With the addition of visual besides the auditory on learning, students gained stronger impression rather than only using audio method. attention sensation that students have is reinforcing each other, what is heard is reinforced by sight (visual), and what is saw is reinforced by heard. (hearing). This literally means that the combined method between visual and audio is truly helping and already been reinforcement for students to have a better understanding about their study.

Psychodrama which has been included in the material is the introduction of "ME", mirroring building 4 dimensions, and bring out students to be more relax and willing to follow the activity happily. So that the peer group discussion, it went well where the participants cooperative and behave openly, and it built students curiosity. Based on the students feeling we can see that before the training, most students felt happy or very happy, and this become more obvious when they were in a smaller class where they know each other well. After the training, there was much more students felt happy and very happy. This result according to Safitri and friends (2015) that concluded group counselling with psychodrama and peer discussion can be used for helping the one (college student) who has problem in running her/his education. Psychodrama here, engage somebody to do some fun activity together, in order to be more open.
In The training "AKU BERANI" (Children is able to protect and defend their self), "BERANI" is the acronyms of B: my body is precious, E: no one is allowed touching me, R: feel if there's something uncomfortable, A: ignore unappropriated invitation, N: No is no, I: remain to keep communication with parents or trusted relatives. Started from bringing the awareness to students by having high dreams, and achieve it also by taking care of them self. Make them realize that their body is so precious by not letting anyone touching inappropriately, no matter who did the force, capable to feel the uncomfortable feeling if something not good happen to them, commit to ignore unappropriated invitation, consistent, saying no to what's not right to do, and always remember to be communicative to the parents and or to their trusted relatives, This is exactly like what Siti Hikmah (2017) found in her study, that prevention of sexual abuse to children will be done through I'm a brave child, and capable to protect .

The peer group discussion results showed that many students already recognized the kind of sexual behavior, either self-experience or from what they saw around them. Those behaviors the students familiar with are whistling, groping, even almost raping has been experienced and or done by the elementary students. For the offender, besides strangers, students already were familiar about the fact that those offender usually were close person, although students who knew this fact just a few.

A December 2009 study by David Finkelhor of UNH and colleagues for the US Justice Department analyzed national sex crime data from 2004. The study said that one in eight juvenile sex offenders were under age 12, between 85 and 95 percent of young offenders would never face another sex charge.

Many students have played games that content pornography. According to Kastlaman M (2007), seeing pornography also raise porn mentality that intends children to do sexual abuse. Therefore this training activity should have been done more often in much more elementary school. Study Ummu Markwei (2019) in Ghana finding the need for effective preventive programs and community interventions to protect children and support victims of child sexual abuse. So this training can be proposed to be one of the programs to prevent sexual abuse in children

Statistical test of the feelings, type knowledge and the offender showing value $p=0,00$, it means there's a significant difference between students' knowledge to their feelings, their knowledge about abuse type and the sexual offender type, before and after training. It can be interpreted that this model is succeeded for early detection of sexual abuse prevention with active learning method

\section{Conclusions}

Based on the questionnaire and discussion results, many students still in the not knowing the kinds of sexual abuse 
and or who possibly could be the offender, but few of them already recognized the kind of sexual behavior, either self-experience or from what they saw around them. The children need to be reminded that the offenders usually are the closest person around them.

The difference test results for effectivity program showing value $p=0.00$, means there's a significant difference between students' knowledge to their feelings, their knowledge about abuse type and the sexual offender, before and after training by active learning method with "AKU BERANI" model. So, this model is succeeded for early detection of sexual abuse prevention with active learning method

\section{Acknowledgement}

Acknowledgement is for KEMENRISTEK DIKTI who already supports this study by funding through the chancellor of Esa Unggul University, under the supervision of LPPM Esa Unggul University. The acknowlegement also for the head principle of SDN01, SDN 11 dan SDN 03 West Jakarta, Faculty of Psychology and Psychology students who helped carry out this research.

We sincerely hope this study will bring advantage for those whom might need.

\section{REFERENCES}

[1] Diesmy Humaira B, dkk (2015), Kekerasan seksual pada anak : Telaah Relasi Korban dan Kerentanan pada Anak, Jurnal Psikoislamika, Fakultas Psikologi Universitas Islam Negeri (UIN)Maulana Malik Ibrahim Malang, Vol 12 Nor 2 $2015 ; 5-10$

[2] Chatib, Munif. (2011). Gurunya Manusia. Kaifa Learning. Bandung

[3] Chris Dornin (2010), Facts and Fiction about Sex Offenders, 29 maret 2019

[4] Hurlock, Elizabeth (2007), Psikologi Perkembangan: Suatu Pendekatan Sepanjang Rentang Kehidupan, Erlangga Jakarta,

[5] http://www.kompasiana.com/dinaindahsari/indonesia-darur at-kekerasan-seksual-anak-save-the children $5768 \mathrm{fb} 70539$ $773 \mathrm{c} 007$, feb 2017

[6] http://manado.tribunnews.com/2018/08/20/pusdatin-komna s-pa-indonesia-catat-angka-kekerasan-seksual-anak-palingtinggi, 29 maret 2019

[7] Ivo Noviana (2015), Kekerasan Seksual Terhadap Anak : Dampak Dan Penanganannya; ejournal.kemsos.go.id/index .php/Sosioinforma/article/download/87/55; 13-28

[8] Kastlemen, Mark (2007); The Drug of The New Millenium; Power Think Publishing, United State of America
[9] Kristen M. Zgoba, Ph.D., and Karen Bachar, Sex Offender Registration and Notification: Limited Effects in New Jersey., U.S. Department of JusticeOffice of Justice ProgramsNational Institute of Justice, April 2019

[10] Safitri, S., \& Luthfi, A. (2013). Peningkatan Pembelajaran Statistika Melalui Metoda Active Learning. Jurnal Psikologi Esa Unggul, ISSN 1907-7483 11(01), 27-38

[11] Safitri, M., Respati, W. S., \& Luthfi, A. (2015). Model Konseling Melalui Psikodrama dan Hipnoterapi untuk Meningkatkan Potensi Mahasiswa, Psychology Forum UMM, ISBN 978-979-796-324-8; 347-353

[12] Sarwono SW; Meinarno E A ( 2017), Psikologi Sosial, Penerbit Salemba Humanika, Jakarta

[13] Siti Hikmah (2017), Mengantisipasi Kejahatan Seksual Terhadap Anak Melalui Pembelajaran "Aku Berani Melindungi Diri Sendiri, Studi di Yayasan al-Hikmah Grobogan , Jurnal SAWWA - Volume 12, Nomor 2, April $2017 ; 187-206$

[14] Sri Maslihah (2013); Play terapi dalam identifikasi kasus kekerasan seksual pada anak; Jurnal penelitian psikologi, Vol 04, No 1, UIN Surabaya; 21-34

[15] Ummu Markwei, Kwaku Osei-Hwedie(2019), Betrayed and Broken: A Study of the Experiences of Victims of Child Sexual Abuse in the Ga Community, Journal of Child Sexual Abuse, received 31 Jul 2018, Accepted 29 Jan 2019 , Published online: 12 Mar 2019 